\title{
Directions, Magnitude, and Efficiency of Interregional Migration, 1970-1990: Jews and Whites in the United States Compared
}

\author{
Uzi Rebhun*
}

\begin{abstract}
This study presents a two-dimensional comparison, over time (1970 and 1990) and intergroup (Jews and total whites), of interregional migration streams. Both lifetime and five-year migration are examined. Data from the 1970/71 and 1990 National Jewish Population Surveys and from the U.S. Censuses of the same years show that the directions of internal migration of Jews and total whites were similar, i.e., from the Northeast and Midwest to the Sunbelt. By 1990, however, net migration for each region-both for the gaining region and for the losing region-had a more significant effect on the Jewish population than on the white population. The initial differences in regional distribution between the two subpopulations have narrowed. Multivariate analysis shows that Jewish migration can largely be explained by educational attainment and employment opportunities. Over time, Jewish migration has become less selective, as seen, inter alia, in the declining importance of denominational identification. The findings are discussed in relation to the integration of Jews into the host society and, more generally, to the geographic dimension of minority status in late 20th century America.
\end{abstract}

\section{INTRODUCTION}

As vital rates, especially fertility, become more homogenous across the United States, there is a growing interest in migration as a key demographic factor responsible for regional growth or decline (Goldstein 1976), as well as for the changes in the geographic distribution of subpopulations that share both historical heritage and common religiocultural values. Comparative studies across subpopulations have focused on racial differentials between blacks and whites (Lee 1974; Lee and Roseman 1999; Long 1988; Long and Hansen 1975) or, more generally, between whites and nonwhites (Bass and Alexander 1972; Serow 1975). However, religioethnic differentials in interstate and interregional migration have received comparatively little attention (Bean, Tienda, and Massey 1987; Belanger and Rogers 1994; Frey 1995a, b; Kobrin and Speare 1983; Sandefur and Jeon 1991). Notwithstanding their significant contributions, some of these studies were limited by data that related to only a single state.

*Division of Jewish Demography and Statistics, The A. Harman Institute of Contemporary Jewry, The Hebrew University of Jerusalem, Israel. Research for this paper was supported by a grant from the Memorial Foundation for Jewish Culture. The author thanks Sergio DellaPergola and Barbara S. Okun for kindly reading a draft of this paper and making valuable suggestions, and Judith Even for editorial assistance. The comments of three anonymous referees were especially helpful. The North American Jewish Data Bank in New York provided the data files of the 1970/71 and 1990 National Jewish Population Surveys. Mr. R. Robinson of CIESIN (Ann Arbor, Michigan) and the Social Science Data Archive of the Hebrew University in Jerusalem made the material of the 1990 U.S. Census available to me. 
The scarcity of empirical evidence has hindered the debate on the nature and role of ethnicity with respect to whether recent demographic and identity processes are evolving towards greater diversity or assimilation of different groups (Alba 1990; Gans 1994; Novak 1972). "Spatial assimilation," i.e., the process whereby a group attains residential propinquity with members of the host society, has been suggested as a "necessary intermediate step between acculturation and other types of assimilation" (Massey and Mullan 1984, p. 837). Since socioeconomic advancement is strongly associated with spatial mobility (Long 1988; Ritchey 1976; White and Mueser 1994; Wolpert 1965), similarity of a group's distribution to that of the majority population indicates behavioral patterns determined by economic opportunities and other nonmonetary rewards, including quality of life, rather than by minority status considerations. Likewise, out-migration from a group's traditional areas of settlement and lower residential concentration may weaken ethnic cohesion and enhance exposure to the general culture. Tracing patterns of migration and trends in the regional distribution of minority groups, in comparison to those of the general white population, is therefore essential for an in-depth understanding of ethnicity in the social context of contemporary America.

Jews are one of the many components of the American religioethnic mosaic. They constitute a small proportion of the total population: Jews were estimated to comprise slightly less than 3 percent of the country's population in 1970 and, due to their stable size over the following two decades (as against total population increase), their relative share declined to 2.2 percent in 1990. Judging from their especially high educational achievements, professional status, and income as compared to most other groups, including non-Jewish whites, the Jews have been thoroughly accepted and integrated into America's social mainstream (Goldstein 1992; Lipset and Raab 1995). This intensive upward socioeconomic mobility, along with the declining importance of familism and friendship (Fishman 1999), has resulted in an increasing rate of internal migration. In an earlier paper, I examined the changing levels of internal migration among Jews and (non-Hispanic) whites during the 1970-90 period (Rebhun 1997a). I showed that interstate lifetime migration rates among Jews increased to levels significantly surpassing those of whites. The proportion of native-born Jewish adults, aged 18 and over, living outside their state of birth almost doubled from 29.1 percent in 1970 to 52.3 percent in 1990, while that of the general white population only increased from 33.8 to 38 percent. This process was observed across different age groups of the Jewish population. Likewise, five-year interstate migration rates of adults in their teens and twenties more than doubled among Jews, while they slightly declined among whites, reversing the trend from lower to higher Jewish rates.

The present article seeks to extend the comparison between Jewish and total white migration by focusing on the direction and magnitude of interregional lifetime and five-year migration streams among the two subpopulations, and the efficiency of these migrations for population redistribution. In addition, an attempt 
is made to determine the role of several factors in explaining Jewish migration in the United States. More specifically, the following questions guide our analysis: a) How did the volume of interregional migration streams among Jews change over the period 1970-90? Gross as well as net exchanges of lifetime and five-year migrations between regions, and the overall net effect of interregional gains or losses on the population, are also measured; $b$ ) To what extent do the trends in Jewish migration follow those observed among the general white population? Comparing the two subpopulations in 1970 and again in 1990 may indicate whether and how migration has similarly or differently affected the size of the two populations at origin and destination and thus their respective geographical distributions; c) How do individual characteristics, socioeconomic context of area of residence, and group identity explain variation in Jewish internal migration, and how have these causal relationships changed over time? Joint consideration of micro- and macrosocial determinants of mobility is expected to improve our understanding of the migration patterns of subpopulations.

Focusing on Jews can partly fill a gap left by the Census, which does not inquire into matters of creed. Religioethnic migration behavior is an understudied topic; much of the national-level ethnic migration research in regional economics has focused on Blacks or Hispanics, whose socioeconomic characteristics are on the whole quite different from those of the Jews. We have here a unique opportunity both for intergroup comparison and for following trends over a relatively long span of twenty years. Given the significant differences in the geographic distributions of Jews and the total white population throughout the first half of the 20 th century, this study can help to broaden our scope on ethnic processes in contemporary America.

Data for this study derive from the National Jewish Population Surveys (NJPS) of 1970/71 and 1990. These are the only nationally representative surveys of American Jewry, and with a sufficient sample size allowing for detailed crosstabulation and analysis. ${ }^{1}$ Not only were these studies conducted almost simultaneously with the United States decennial Censuses, but they also asked identical migration questions. ${ }^{2}$ The data on migration come from 1970 and 1990 NJPS and United States Census questions on state of birth, residence five years earlier, and current residence. These studies also provide data on other individual characteristics of the populations under discussion, whereas data for the contextual measures are drawn from various official sources.

\footnotetext{
${ }^{1}$ Both surveys obtained probability samples of the American Jewish population. Each survey randomly selected a sample household respondent from among the adult Jewish household residents: in the 1970/71 survey the Kish selection table technique was used, while in the 1990 survey an equivalent approach of "the next birthday" was applied to all Jewish household residents. In both surveys, basic personal information was collected for all household members. Data were weighted to account for their differential selection probabilities. Further, we divided each respondent weight by the average weight to ensure representativeness without changing the original sample size. In this study, we make use of data for persons identified as Jews. For a detailed description of the methodology of the 1970/71 and 1990 NJPS, see Rebhun (1997a).

2Data for the 1970 and 1990 total white population were taken from printed reports of the U.S. Censuses of these years. Some data for the 1990 white population were obtained from a subfile of the $1 \%$ Public Use Microdata Sample (PUMS).
} 


\section{MIGRATION AND REDISTRIBUTION DYNAMICS AMONG ETHNIC GROUPS: EXISTING EVIDENCE}

The scholarly literature on internal migration and redistribution of ethnic minorities and of total whites, though not copious, has produced interesting findings that contribute to our understanding of the presence of various subpopulations throughout the country. The emerging patterns are not always consistent; they vary over time, space (i.e., whether interstate or interregional migration), and between ethnic groups. In general, the direction of internal migration over time among minority groups converged with the patterns exhibited by the general white population. In other cases, initial population distribution different from that of the white majority produced contrary movements. Overall, however, the variations in geographical distribution diminished substantially. The rhythm of mobility differs from one group to another depending largely on individual characteristics and ethnic variables. Non-Hispanic whites migrate from states receiving large inflows of minority immigrants, which contributes to spatial distinctiveness along ethnic lines.

Using data from three consecutive Censuses, Sandefur and Jeon (1991) show that in the late 1960s whites migrated mainly from the Northeast and Midwest to the South and West. Net migration for the native-born members of major minority groups often varied: the Northeast gained Asians and American Indians, the Midwest gained Hispanics, and the South had a net out-migration of Asians and Hispanics. Only the West attracted both whites and minority populations in numbers exceeding those of out-migrants. By 1975-80, the patterns of net migration for whites and minority groups had become more similar. Among all groups, the Northeast and Midwest lost population to the Sunbelt regions. Overall, during the 1960-80 period, intergroup differences in regional distribution between whites and native minorities narrowed somewhat.

A comparison between interregional migration patterns of the native-born and foreign-born populations living in the United States in 1965 suggests that during the next five years (1965-70) both groups had a net loss in the Northeast and Midwest and a net gain in the South and West (Belanger and Rogers 1994). Nevertheless, the total effect for the foreign-born population is the sum total of differences according to ethnic origin. Mexican- and Asian-born groups showed a net out-migration from the South and the Puerto Rican-born showed a net out-migration from the West. Thus, their migration patterns differed from those of other Hispanic populations. By 1975-80, the negative net migration for the Northeast and Midwest and the positive net migration for the two Sunbelt regions characterized all foreign-born populations, thus enhancing intergroup similarity in migration behavior, presumably in response to economic changes and opportunities.

Bean, Tienda, and Massey (1987) add to the above observations on Hispanics by analyzing jointly the foreign-born and the native-born populations for the years 1975 to 1980 . Among certain groups, including the Cubans, the tendency to leave the Northeast and Midwest for the South was especially pronounced. 
Likewise, among the non-Hispanic whites and Spanish origin groups, the South gained from each of the other three regions, the West gained from the Northeast and Midwest, and the Midwest experienced net in-migration from the Northeast region. Only in the case of Other Hispanics (other than Mexicans, Puerto Ricans, Cubans, and Central/South Americans) was it the West, rather than the South, that had a positive net migration from the other three regions. A more detailed analysis of the migration among the different regions reveals that the overwhelming majority of non-Hispanic whites who moved interregionally were destined for the South. Similar patterns were found among Hispanics, particularly Cubans and Mexicans. Both among non-Hispanic whites and Hispanics (with the exception of Cubans), there was a strong tendency to move to the West irrespective of region of origin. These spatial movements resulted in a lower geographic concentration of the native-born population of Spanish origin than that of their foreign-born counterparts.

More recently, Frey (1995a) showed that states with large inflows of minority immigrants, such as New York, Illinois, Massachusetts, and Texas, lost white (non-Hispanic) internal migrants. States that grew primarily as a result of internal migration during the $1985-90$ period were those "in the economically booming South Atlantic region as well as in the West" (Frey 1995a, p. 285). Even in California, the number of immigrants was far larger than the positive net balance of internal migration. The out-migration of whites from minority-dominant immigration states is, to a large extent, a response to job competition; hence, it is led by people with less-than-college education and low incomes. This pattern differs from the long-distance migration that typically involves the medium and high socioeconomic strata. Further, these out-migrants are responding to the increased social costs of the changing race and ethnic composition of these states' populations. Many of the migrants are destined for adjacent states (Frey 1995b). The internal migration of ethnic minorities has largely followed the patterns exhibited by total whites, namely to nearby states, though at a much slower pace. If this immigrationinternal migration dynamic continues, ethnic "balkanization" is likely to develop across broad areas of the country. Challenging this thesis, Wright, Ellis, and Reibel (1997) and Kritz and Gurak (2001), among others, suggested that both the nativeborn and the foreign-born were less likely to leave states with high immigration than they were to leave other states, and that internal migration of natives is a response to individual characteristics and structural conditions within areas rather than to competition with recent immigrants.

Out-migration from Rhode Island over the period 1968-79 revealed substantial ethnic variation (Kobrin and Speare 1983). Jews had the highest rate of out-migration. Among Protestant and Catholic subgroups, the former were more likely to migrate. This is partly explained by individual characteristics, but a more significant proportion of the variation is attributed to ethnic, social, and economic cohesion. The role of these variables in determining out-migration from Rhode Island differs among the ethnic groups. While some groups, including English 
Protestants, Irish, French Canadians and "other" Catholics, are very sensitive to these variables, other factors explain the distinctively high out-migration rate of West European Protestants and the very low rate of "other" Protestants. Italians and Portuguese comprise a third group of very homogenous ethnic communities. Although individual and ethnic variables are significant predictors of migration behavior, membership in either of these ethnic groups contributes to a lower outmigration rate. Out-migration of Jews is mainly determined by the individual's characteristics and to a lesser extent by ethnic variables.

Differences in interstate migration were also found among American Indian couples as compared to white couples or intermarried couples of whites and American Indians, with the former having considerably lower rates (Sandefur 1986). These differentials did not disappear after controlling for other determinants of migration such as education, family size, and level of health.

Despite some exceptions, the more recent trends in internal migration display greater similarity between the total white population and the major ethnic minorities. Significant differences still persist in the rhythm of migration and in the relative impact of these movements on the spatial redistribution of the various subgroups across the country. The present paper challenges similar preconceived ideas with regard to the American Jewish population and attempts to provide, at both the individual and the macro level, some socioeconomic explanations for these movements and to evaluate their long-term cultural consequences.

\section{REGIONAL TRENDS AND DIFFERENCES IN MIGRATION STATUS}

\section{Lifetime Migration Status by Region of Residence}

The 1970 NJPS documented significant regional differences in the levels of interstate lifetime mobility (Table 1). The overwhelming majority of native-born Jews in the South and West lived at that time in states other than their states of birth, having made either an intraregional or interregional move. Interstate migration was much less prevalent among residents of the Northeast and Midwest.

\section{TABLE 1}

Region of Residence, by Lifetime Migration Status: Jews and Whites Aged 18 and Over in 1970 and in 1990 (Percent)

\begin{tabular}{|c|c|c|c|c|c|c|c|}
\hline \multirow[b]{2}{*}{$\begin{array}{l}\text { Region of Residence } \\
\text { at Time of Survey/ } \\
\text { Census }\end{array}$} & \multicolumn{3}{|c|}{ Migration Status, 1970} & \multicolumn{3}{|c|}{ Migration Status, 1990} & \multirow{2}{*}{$\begin{array}{c}\text { Ratio } \\
\text { (E) /(B) } \\
\text { (G) }\end{array}$} \\
\hline & $\mathrm{N}^{\mathrm{a}} \mathrm{O}$ & $\begin{array}{l}\text { Different State } \\
\text { Out of Native-Born } \\
\text { (B) }\end{array}$ & $\begin{array}{l}\text { Foreign- } \\
\text { Bornb } \\
\text { (C) }\end{array}$ & $\begin{array}{l}\mathrm{N}^{\mathrm{a}} \\
\text { (D) }\end{array}$ & $\begin{array}{l}\text { Different State } \\
\text { Out of Native-Born } \\
(\mathrm{E})\end{array}$ & $\begin{array}{l}\text { Foreign- } \\
\text { Bornb } \\
\text { (F) }\end{array}$ & \\
\hline $\begin{array}{l}\text { Total } \\
\text { Northeast } \\
\text { Midwest } \\
\text { South } \\
\text { West }\end{array}$ & $\begin{array}{r}(12,599) \\
(7,583) \\
(2,076) \\
(1,495) \\
(1,445)\end{array}$ & $\begin{array}{l}29.1 \\
17.6 \\
23.9 \\
64.8 \\
61.4\end{array}$ & $\begin{array}{c}\text { Jews } \\
19.8 \\
19.3 \\
19.0 \\
22.2 \\
20.6 \\
\text { Whites }\end{array}$ & $\begin{array}{r}(3,365) \\
(1,486) \\
(366) \\
(749) \\
(764)\end{array}$ & $\begin{array}{l}50.8 \\
31.6 \\
39.4 \\
78.3 \\
66.7\end{array}$ & $\begin{array}{r}10.2 \\
10.5 \\
6.3 \\
8.9 \\
12.7\end{array}$ & $\begin{array}{l}1.75 \\
1.80 \\
1.65 \\
1.20 \\
1.09\end{array}$ \\
\hline $\begin{array}{l}\text { Total } \\
\text { Northeast } \\
\text { Midwest } \\
\text { South } \\
\text { West }\end{array}$ & $\begin{array}{r}(109,613) \\
(28,342) \\
(32,337) \\
(31,020) \\
(17,914)\end{array}$ & $\begin{array}{l}33.8 \\
20.8 \\
27.0 \\
34.9 \\
65.0\end{array}$ & $\begin{array}{r}7.2 \\
12.9 \\
5.0 \\
2.2 \\
8.0\end{array}$ & $\begin{array}{r}(147,536) \\
(31,946) \\
(37,603) \\
(48,160) \\
(29,827)\end{array}$ & $\begin{array}{l}38.0 \\
24.2 \\
26.5 \\
44.0 \\
58.1\end{array}$ & $\begin{array}{l}6.2 \\
8.5 \\
3.2 \\
4.9 \\
9.8\end{array}$ & $\begin{array}{l}1.12 \\
1.16 \\
0.98 \\
1.26 \\
0.89\end{array}$ \\
\hline
\end{tabular}

${ }^{\mathrm{a}}$ For Jews: weighted, divided by the average weighting factor to arrive at the actual sample size. For whites: in thousands.

${ }^{b}$ Does not include persons born in Puerto Rico, in outlying areas, or born abroad to American parents. 
During the next two decades, the rate of interstate migration increased in all regions. Although the rates remained highest in the Sunbelt regions, the Northeast and the Midwest experienced the greatest increase. We can infer that despite large net out-migration from the Northeast and Midwest (Goldstein and Goldstein 1996), the dynamics of intraregional mobility, and perhaps in-migration to these regions as well, have accelerated. Moreover, it is now evident that the rise in interstate lifetime migration among Jews characterized all age groups and both gender groups (Rebhun 1997b), as well as all regions of the United States.

The observations of increasing rates of interstate lifetime migration among the general white population were apparently selective and did not apply to all regions. The trend towards higher levels of mobility applies to the Northeast and the South, while the Midwest and the West experienced a decline in the proportion of interstate lifetime migrants during the period 1970-90 (Table 1). The intergroup comparison shows that, with the exception of the South, whites had higher rates of interstate migration in 1970 than did Jews; by 1990, the rates were already much higher among Jews in all four regions.

\section{Five-Year Migration Status by Region of Residence}

The data for five-year interstate movers by region of residence closely coincide with the trends revealed by the lifetime migration measure (Table 2). Between 1970 and 1990, the percentage of Jews both in the Northeast and Midwest who had moved between states during the preceding five years increased. In contrast, the percentage of recent interstate migrants among Jews who lived in the South and West in 1990 declined. $^{3}$

\section{TABLE 2}

Region of Residence, by Five-Year Migration Status: Jews and Whites Aged 18 and Over in 1970 and in 1990 (Percent)

\begin{tabular}{|c|c|c|c|c|c|c|c|}
\hline \multirow[b]{2}{*}{$\begin{array}{l}\text { Region of Residence } \\
\text { at Time of Survey/ } \\
\text { Census }\end{array}$} & \multicolumn{3}{|c|}{ Migration Status, 1970} & \multicolumn{3}{|c|}{ Migration Status, 1990} & \multirow{2}{*}{$\begin{array}{c}\text { Ratio } \\
\text { (E)/(B) } \\
\text { (G) }\end{array}$} \\
\hline & $\begin{array}{l}\mathrm{N}^{\mathrm{a}} \\
\text { (A) }\end{array}$ & $\begin{array}{l}\text { Different State } \\
\text { Out of Residing } \\
\text { in } 1965 \text { in U.S. } \\
\text { (B) }\end{array}$ & $\begin{array}{c}\text { Abroad } \\
\text { in } 1965 \\
\text { (C) }\end{array}$ & $\begin{array}{l}\mathrm{N}^{\mathrm{a}} \\
\text { (D) }\end{array}$ & $\begin{array}{l}\text { Different State } \\
\text { Out of Residing } \\
\text { in } 1985 \text { in U.S. } \\
\text { (E) }\end{array}$ & $\begin{array}{c}\text { Abroad } \\
\text { in } 1985 \\
\text { (F) }\end{array}$ & \\
\hline $\begin{array}{l}\text { Total } \\
\text { Northeast } \\
\text { Midwest } \\
\text { South } \\
\text { West }\end{array}$ & $\begin{array}{r}(12,469) \\
(7,552) \\
(2,053) \\
(1,481) \\
(1,383)\end{array}$ & $\begin{array}{r}9.6 \\
6.6 \\
6.7 \\
23.9 \\
15.9\end{array}$ & $\begin{array}{l}\text { Jen } \\
2.4 \\
1.3 \\
2.7 \\
7.5 \\
2.3 \\
\text { Whi }\end{array}$ & $\begin{array}{r}(3,376) \\
(1,496) \\
(367) \\
(747) \\
(766)\end{array}$ & $\begin{array}{r}10.3 \\
7.5 \\
11.5 \\
17.4 \\
8.5\end{array}$ & $\begin{array}{l}1.0 \\
0.7 \\
0.1 \\
1.6 \\
1.6\end{array}$ & $\begin{array}{l}1.07 \\
1.14 \\
1.72 \\
0.73 \\
0.53\end{array}$ \\
\hline $\begin{array}{l}\text { Total } \\
\text { Northeast } \\
\text { Midwest } \\
\text { South } \\
\text { West }\end{array}$ & $\begin{array}{r}(109,991) \\
(28,511) \\
(32,253) \\
(30,910) \\
(18,317)\end{array}$ & $\begin{array}{r}9.6 \\
6.3 \\
7.3 \\
12.7 \\
13.8\end{array}$ & $\begin{array}{l}1.5 \\
1.7 \\
0.8 \\
1.1 \\
1.9\end{array}$ & $\begin{array}{r}(151,781) \\
(32,739) \\
(38,916) \\
(50,029) \\
(30,097)\end{array}$ & $\begin{array}{r}10.0 \\
7.3 \\
7.2 \\
12.5 \\
12.6\end{array}$ & $\begin{array}{l}1.2 \\
1.2 \\
0.6 \\
1.2 \\
2.2\end{array}$ & $\begin{array}{l}1.04 \\
1.15 \\
0.99 \\
0.98 \\
0.91\end{array}$ \\
\hline
\end{tabular}

a See NOTE (a) to Table 1.

${ }^{3}$ As Goldstein (1983) pointed out, some interstate movements, especially in the Northeast, "could, in fact, be equivalent to suburbanization given the smaller size of the states and the existence of many metropolitan areas that extend across boundaries. This possibility is less likely in the South and the West where states are larger..." (p. 326). 
These trends were observed among Jewish men and women alike (Rebhun 1997b); yet, the pace of change-whether of the increasing interstate migration rate in the Northeast and Midwest or the decline in the sunbelt regions-was more pronounced among women. This can be attributed to trends in the social and economic mobility of Jewish women and to changes in family characteristics. Over the last few decades, Jewish women in the United States have almost entirely closed the once wide gender gap in educational attainment. Similarly, the occupational distribution of Jewish women has largely converged with that of men, with a substantial concentration in professional and managerial occupations. From a comparative point of view, "the Jewish presence among total U.S. professionals, much above their share in the total labor force, is...even more remarkable among women than among men" (DellaPergola 2000, p. 214). Likewise, the participation of Jewish women in the labor force increased between the late 1950s and 1990, while that of Jewish men decreased slightly. Taking into account recent trends in family patterns, including later age at marriage, growing rates of divorce, and more single-parent families (which are often headed by women who carry most of the burden of family destabilization), it is likely that women would be more sensitive to economic opportunities and would respond somewhat quickly and coherently to changes in the national labor market through migration.

Despite the decline in the proportion of five-year interstate migrants in the South, the Jewish population in the region nevertheless retained the highest percentage of recent movers. A large proportion of them are retirees seeking a warm climate who are less influenced by local economic developments (Assadian 1995). ${ }^{4}$

While generally following patterns similar to those that characterized the total white population, changes were more pronounced (except in the Northeast) for Jews (Table 2, Column G). ${ }^{5}$ In the Midwest, the accelerated increase among Jews reversed the previous differentials and, by 1990, Jews had higher rates of recent migration than whites. In the South, the rates of recent interstate migration converged to a large extent. Only in the West were Jews found to be a less mobile population than whites, thus reversing the differences observed in 1970.

\section{INTERREGIONAL LIFETIME MIGRATION FLOWS}

\section{The Jewish Population}

In 1970, substantial regional variations were found in the percentage of adult Jews who had been born in a state other than their current state of residence and had moved in from other regions, with the West having the highest level and the Northeast the smallest (Table 3). The data on the percent distribution of interregional migrants show that Jewish migration was directed westward and southward with an overwhelming majority of migrants into these areas originating in the Northeast. Of the much smaller number of migrants going to the Northeast,

${ }^{4}$ The proportion of elderly aged 65 and over among Jewish migrants to Florida was more than twice the proportion among all Jewish interstate migrants over the $1985-90$ period.

${ }^{5}$ Still, Jews exhibit a higher rate of interstate migration than total whites. The stronger propensity of Jews to move, as compared to other religious and ethnic groups, is documented in out-migration rates from Rhode Island over the period 1968-79 (Kobrin and Speare 1983). 
slightly less than half were born in the West and the South. Lifetime migration patterns among the Jewish population in 1990 closely paralleled those observed twenty years earlier. Within these rather continuous flows, the percentage of Jews born in the West among interregional migrants to the Northeast has increased.

TABLE 3

Region of Residence, by Region of Birth for Native-Born Persons Living Out of their State of Birth: Jews and Whites Aged 18 and Over in 1970 and in 1990 (Percent)

\begin{tabular}{|c|c|c|c|c|c|c|c|c|}
\hline \multirow[b]{2}{*}{ Region of Birth } & \multicolumn{4}{|c|}{ Region of Residence, 1970} & \multicolumn{4}{|c|}{ Region of Residence, 1990} \\
\hline & Northeast & & & West & Northeast & & South & West \\
\hline \multicolumn{9}{|c|}{ Percent Distribution of Interstate Migrants } \\
\hline Total & 100.0 & 100.0 & 100.0 & 100.0 & 100.0 & 100.0 & 100.0 & 100.0 \\
\hline & $(1,136)$ & (419) & (787) & (735) & $(409)$ & (133) & $(531)$ & $(443)$ \\
\hline Northeast & 80.5 & $54.4^{\prime}$ & 62.1 & 51.2 & 71.9 & 43.8 & 67.8 & 50.2 \\
\hline Midwest & 10.6 & 29.9 & 8.6 & 36.9 & 10.5 & 36.6 & 15.2 & 30.5 \\
\hline South & 7.5 & 7.6 & 27.8 & 5.4 & 11.0 & 13.4 & 12.2 & 7.6 \\
\hline \multirow{2}{*}{\multicolumn{9}{|c|}{$\begin{array}{l}\text { West } \\
\text { Percent Distribution of Interregional Migrants }\end{array}$}} \\
\hline & & & & & & & & \\
\hline $\begin{array}{l}\text { Total } \\
\mathrm{N}^{\mathrm{a}}\end{array}$ & $\begin{array}{c}100.0 \\
(221)\end{array}$ & $\begin{array}{c}100.0 \\
(294)\end{array}$ & $\begin{array}{c}100.0 \\
(568)\end{array}$ & $\begin{array}{c}100.0 \\
(688)\end{array}$ & $\begin{array}{c}100.0 \\
(115)\end{array}$ & $\begin{array}{r}100.0 \\
(84)\end{array}$ & $\begin{array}{c}100.0 \\
(465)\end{array}$ & $\begin{array}{c}100.0 \\
(391)\end{array}$ \\
\hline Northeast & & 77.6 & 86.1 & 54.7 & & 69.0 & 77.2 & 56.8 \\
\hline & 54.3 & & 12.0 & 39.5 & 37.4 & & 17.4 & 34.5 \\
\hline & 38.5 & 10.9 & & 5.8 & 39.1 & 21.4 & & 8.7 \\
\hline West & 7.2 & 11.5 & 1.9 & - & 23.5 & 9.6 & 5.4 & - \\
\hline \multicolumn{9}{|c|}{ Whites } \\
\hline \multicolumn{9}{|c|}{ ation of Interstate Migrants } \\
\hline $\begin{array}{l}\text { Total } \\
\mathrm{N}^{\mathrm{a}}\end{array}$ & 100.0 & $\begin{array}{l}100.0 \\
(8.299)\end{array}$ & $\begin{array}{l}100.0 \\
(10.619)\end{array}$ & $\begin{array}{l}100.0 \\
(10.707)\end{array}$ & $\begin{array}{l}100.0 \\
(7.087)\end{array}$ & $\begin{array}{l}100.0 \\
(9,631)\end{array}$ & $\begin{array}{l}100.0 \\
(20.166)\end{array}$ & $\begin{array}{l}100.0 \\
(15,614)\end{array}$ \\
\hline Northeast & 67.5 & 14.5 & 20.6 & 14.1 & 66.1 & 14.4 & 25.2 & 17.1 \\
\hline Midwest & 15.0 & 50.8 & 23.1 & & 14.9 & 51.3 & 26.8 & 38.7 \\
\hline South & 14.2 & 29.9 & 51.8 & 21 & 13. & 26. & 40 & 18.3 \\
\hline West & 3.3 & 4.8 & 4.5 & 20.2 & 5.1 & 8.2 & & 25.9 \\
\hline \multicolumn{9}{|c|}{ Percent Distribution of Interregional Migrants 4.5} \\
\hline $\begin{array}{l}\text { Total } \\
\mathrm{N}^{\mathrm{a}}\end{array}$ & $\begin{array}{l}100.0 \\
(1,670)\end{array}$ & $\begin{array}{l}100.0 \\
(4,092)\end{array}$ & $\begin{array}{l}100.0 \\
(5,118)\end{array}$ & $\begin{array}{l}100.0 \\
(8,540)\end{array}$ & $\begin{array}{l}100.0 \\
(2,404)\end{array}$ & $\begin{array}{l}100.0 \\
(4,695)\end{array}$ & $\begin{array}{l}100.0 \\
(11,910)\end{array}$ & $\begin{array}{l}100.0 \\
(11,563)\end{array}$ \\
\hline Northeast & & 29.4 & 42.8 & 17.7 & - & 29.6 & 42.7 & 23.1 \\
\hline Midwest & 46.1 & - & 47.9 & 56. & 44. & - & 45.3 & 52.2 \\
\hline Sout & 43.6 & 60.7 & - & 26.2 & 41.0 & 53.6 & - & 24.7 \\
\hline West & 10.3 & 9.9 & 9.3 & - & 14.9 & 16.8 & 12.0 & - \\
\hline
\end{tabular}

Source: Rebhun (1997a).

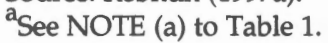

Consistent with the data on percent distribution of interregional migrants, by 1970 the Northeast had a negative migration balance with all regions (Table 4). While the Midwestern states gained from their exchange with the Northeast, they lost to the South and West, resulting in a net out-migration. More Jews moved from the South to the West than the other way around; overall, however, the South gained Jewish population through interregional lifetime movements. The West gained from all other parts of the United States, drawing most heavily from the Northeast and Midwest.

The directional signs of the net interchanges between regions remained unchanged over the interval 1970-90. In fact, the overall effect of interregional gains and losses became more pronounced in most cases. This reflects the cumulative effect of interregional migration flows and, perhaps, an increasingly welldefined pattern as well. 


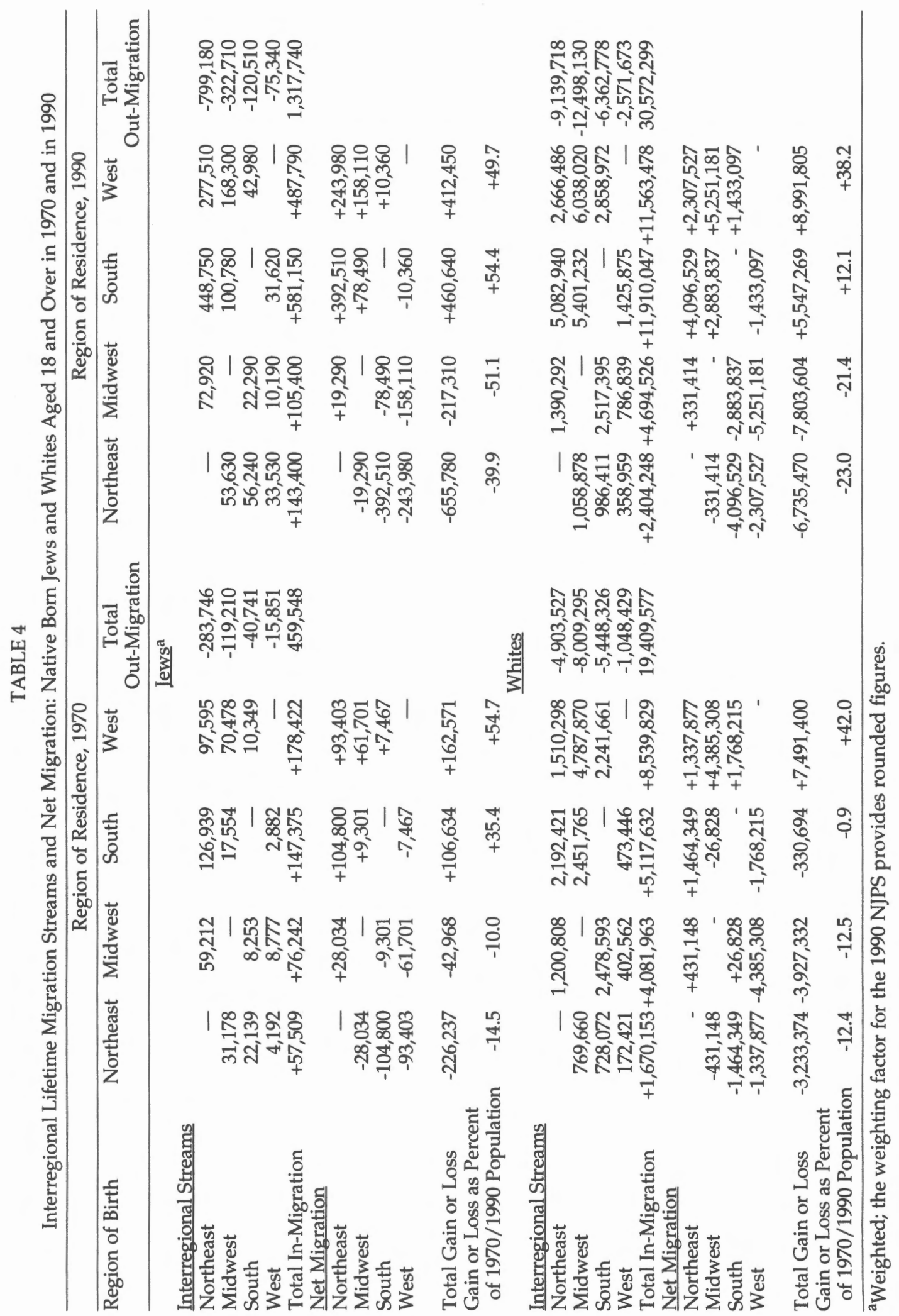


I also calculated the efficiency of migration in redistributing the population across regions. Among Jews in 1970, the most efficient lifetime migration was to the West and from the Northeast (Figure 1). By 1990, the efficiency of migration to the West had declined slightly, while the Northeast was losing population more efficiently than before. These two regions remained the most efficient gainer and loser, respectively, of Jewish population through migration. However, efficiency of net in-migration to the South and of out-migration from the Midwest have increased. The total efficiency of interregional lifetime migration in population redistribution increased: while each 100 moves among Jews in 1970 brought about a net redistribution of 59 persons, this was true for 66 of every 100 moves among Jews in 1990.

\section{FIGURE 1}

Lifetime Migration Efficiency: Jews

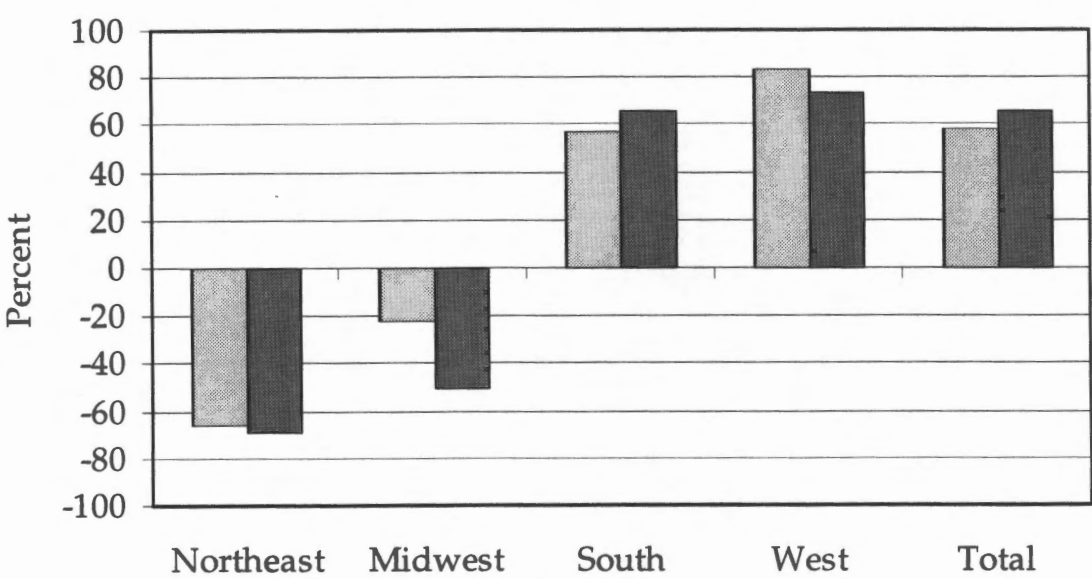

뭄 1990

Lifetime Migration Efficiency: Total Whites

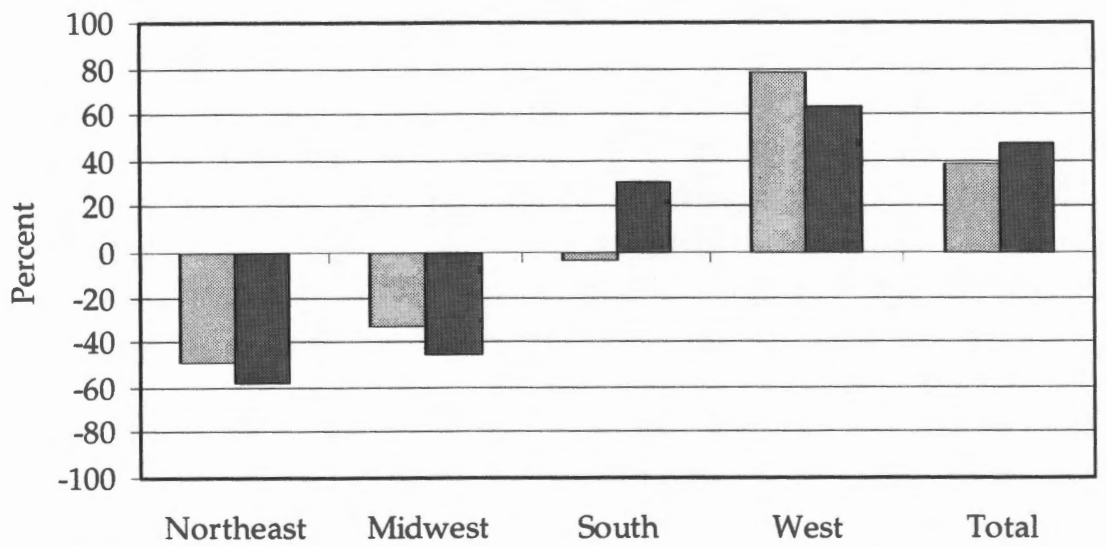




\section{Total White Population}

Among the total white population, distance seems to have played an important role in determining migration behavior (Table 3). In 1970, the percentage of intraregional migrants among all interstate movers, with the exception of those in the Northeast, was fairly high-substantially higher than among Jews. A look at the region of origin for white interregional migrants shows that they moved primarily toward the Sunbelt. However, as compared to Jews, a higher proportion of the general white population originated in the Midwest. Moreover, the data point to a substantial countermovement, as seen in the high proportion of those born in the Sunbelt regions among the in-migrants to the Northeast and Midwest. The findings from the 1990 Census reveal no significant changes in the origins of in-migration for any of the four regions.

The matrix of interregional migration streams shows that the Northeast lost white population to all other regions (Table 4). The Midwest gained from both the Northeast and the South; however, these increments failed to compensate for a much larger net loss to the West, resulting in an overall net out-migration. The South was characterized by a near balance of gains and losses. The West gained some 7.5 million whites from all other regions-a number equivalent to 42 percent of its adult white population. While labor force migration since the termination of World War II, especially to California, is essential in these streams, other incentives were also at play, including cultural lifestyles and environmental amenities (Long 1988).

By 1990, the South had already gained from the Midwest through lifetime migration. The rest of the interchanges retained their positive or negative signs. However, the overall net effect of out-migration from the Northeast and Midwest almost doubled, while net in-migration to the West declined slightly. The latter trend may be associated with California's loss of some of its attractiveness for people from other states as well as its ability to retain its own people (Long 1988).

Overall, in both 1970 (with the exception of the Midwest) and 1990, lifetime migration more strongly affected the size of the Jewish population than the white population in each region. Furthermore, in both 1970 and 1990, lifetime migration was more efficient in redistributing Jews than whites (Figure 1). We can infer that, due to greater similarity in education and occupation, Jews respond more uni-directionally and coherently to social and economic stimuli. By contrast, the total whites are a far more heterogeneous population, including a few ethnic groups, each of which might have somewhat different social and cultural attributes. Thus, different sets of stimuli may be affecting them independently, leading to more in- and out-migration from the same region.

The continuation and acceleration of interregional population shifts among Jews and total whites reflect the cumulative effects of changes in population composition, in the location of certain industrial sectors, and in the national economy in general. During the 1970s and early 1980s, the large baby-boom generation came of age and was motivated by economic incentives of significant 
increases in nonagricultural jobs in the South and West (Greenwood 1988). The 1970s, with the energy crisis and deep recession, witnessed fundamental economic restructuring away from manufacturing and toward service and tertiary and quaternary sector activities (Greenwood 1988; Plane 1989). The recessionary conditions of the early 1980 s were even more severe, particularly hurting the highly concentrated steel and automobile industries in the metropolitan areas of the Northeast and Midwest.

The restructuring of the regional economy made it difficult for the traditional national core regions to provide jobs for the increasing demand that historically shoved migrants out of the South (Plane 1989). Migration patterns were further affected by job relocations in the government sector. This includes military base employment, which, during the military building of the 1980s, was more widely spread throughout the country, and the rapidly growing economic component of state and local government employment, which experienced significant demands for new jobs in the South and West (Plane 1989).

Some employment turnarounds since the mid-1980s have strengthened the retention of potential movers out of the Northeast and Midwest, including years of positive migration balance between core states and energy-based states. Economic transformations, such as the growing defense-related industries in New England (Barff and Knight 1988), the adoption of new forms of work and production organization in the Midwest (Florida 1996), and the dramatic decline in employment in the oil industry, which was heavily concentrated in the WestSouth-Central and Mountain regions (McHugh and Gober 1992), may be better manifested in patterns of recent migration.

\section{INTERREGIONAL FIVE-YEAR MIGRATION FLOWS}

\section{The Jewish Population}

The distribution of regions of origin from which Jews made five-year interstate moves changed considerably between $1965-70$ and 1985-90. This was only partly reflected in the measure of lifetime migration, which seems to have summarized different processes in the last two decades. Perhaps most noticeable are the trends in the Northeast, where the percentage of interstate migrants within their own region of residence declined, and in the West, where the proportion of intraregional migrants increased (much of the movement between 1985 and 1990 was from the Pacific division to the Mountain division) (Table 5). Moreover, between the late 1960s and late 1980s, the percentage of migrants arriving in the Sunbelt regions from the Northeast diminished. A follow-up over time reveals that both the Midwest and the South experienced significant increases in the proportion of migrants from the West. These trends are seen more clearly if only interregional migrants are considered. 


\section{TABLE 5}

Region of Residence, by Region of Residence Five Years Earlier for Interstate Migrants: Jews and Whites Aged 18 and Over in 1970 and in 1990 (Percent)

\begin{tabular}{|c|c|c|c|c|c|c|c|c|}
\hline \multirow{2}{*}{$\begin{array}{l}\text { Region of } \\
\text { Residence } \\
1965 / 1985\end{array}$} & \multicolumn{4}{|c|}{ Region of Residence, 1970} & \multicolumn{4}{|c|}{ Region of Residence, 1990} \\
\hline & Northeast & Midwest & South & West & Northeast & Midwest & South & West \\
\hline \multicolumn{9}{|c|}{ Percent Distribution of Interstate Migrants } \\
\hline Total & 100.0 & 100.0 & 100.0 & 100.0 & 100.0 & 100.0 & 100.0 & 100.0 \\
\hline $\mathrm{N}^{\mathrm{a}}$ & $(511)$ & (126) & $(320)$ & $(81)$ & $(108)$ & $(42)$ & $(127)$ & (63) \\
\hline Northeast & 75.7 & 26.2 & 66.6 & 54.3 & 51.4 & 26.2 & 42.0 & 23.9 \\
\hline Midwest & 4.9 & 29.4 & 8.8 & 21.0 & 16.7 & 38.3 & 12.7 & 18.8 \\
\hline South & 12.1 & 37.3 & 24.1 & 1.2 & 27.1 & 23.3 & 33.6 & 19.9 \\
\hline West & 7.3 & 7.1 & 0.3 & 23.5 & 4.8 & 12.2 & 11.7 & 37.4 \\
\hline \multicolumn{9}{|c|}{ Percent Distribution of Interregional Migrants } \\
\hline Total & 100.0 & 100.0 & 100.0 & 100.0 & 100.0 & 100.0 & 100.0 & 100.0 \\
\hline $\mathrm{N}^{\mathrm{a}}$ & $(124)$ & (89) & $(243)$ & $(62)$ & (53) & (26) & (84) & (40) \\
\hline Northeast & - & 37.1 & 87.7 & 71.0 & - & 42.3 & 63.1 & 38.4 \\
\hline Midwest & 20.2 & - & 11.5 & 27.4 & 34.6 & - & 19.0 & 30.8 \\
\hline South & 50.0 & 52.8 & - & 1.6 & 55.8 & 38.5 & - & 30.8 \\
\hline West & 29.8 & 10.1 & 0.8 & - & 9.6 & 19.2 & 17.9 & - \\
\hline \multicolumn{9}{|c|}{ Percent Distribution of Interctate Miorantc } \\
\hline Percent Dis & ution of Int & rstate Mig & & & & & & \\
\hline Total & 100.0 & 100.0 & 100.0 & 100.0 & 100.0 & 100.0 & 100.0 & 100.0 \\
\hline$N^{a}$ & $(1,767)$ & $(2,342)$ & $(3,870)$ & $(2,490)$ & $(2,372)$ & $(2,794)$ & $(6,161)$ & $(3,704)$ \\
\hline Northeast & 54.1 & 13.0 & 19.2 & 13.2 & 51.3 & 9.3 & 20.6 & 10.7 \\
\hline Midwest & 15.6 & 46.7 & 22.9 & 27.3 & 11.7 & 43.4 & 20.6 & 20.2 \\
\hline South & 20.7 & 24.5 & 45.3 & 19.2 & 24.1 & 29.5 & 45.8 & 21.9 \\
\hline West & 9.6 & 15.8 & 12.6 & 40.3 & 12.9 & 17.8 & 13.0 & 47.2 \\
\hline \multicolumn{9}{|c|}{ Percent Distribution of Interregional Migrants } \\
\hline Total & 100.0 & 100.0 & 100.0 & 100.0 & 100.0 & 100.0 & 100.0 & 100.0 \\
\hline $\mathrm{N}^{\mathrm{a}}$ & (811) & $(1,249)$ & $(2,119)$ & $(1,486)$ & $(1,155)$ & $(1,581)$ & $(3,342)$ & $(1,957)$ \\
\hline Northeast & - & 24.4 & 35.1 & 22.1 & - & 16.5 & 38.1 & 20.4 \\
\hline Midwest & 33.9 & - & 41.9 & 45.8 & 24.0 & - & 38.0 & 38.2 \\
\hline South & 45.1 & 46.0 & - & 32.1 & 49.4 & 52.0 & - & 41.4 \\
\hline West & 21.0 & 29.6 & 23.0 & - & 26.6 & 31.5 & 23.9 & - \\
\hline
\end{tabular}

${ }^{a}$ See NOTE (a) to Table 1.

The marked increase from 1965-70 to 1985-90 in the magnitude of interregional movement to the Northeast from the Midwest resulted in a reverse of the net migration between these two regions from negative to positive (Table 6). A similar trend from the South to the Northeast was not significant enough to offset a much larger countermovement, and the migration balance between the Northeast and South remained negative. Between the late 1960s and the late 1980s, the net balance between the Northeast and the West increased. All migration rates of the Northeast-out-migration figures constructed on an "at risk" basis, in-migration rate based on end-of-period population, and net migration rate based on the surviving beginning-of-period population-have increased.

It is now evident that the increase in the percentage of interstate migrants in the Midwest was a result of trends in interstate migration within the region (Table 5), as well as the increasing attractiveness of the Midwest for Jews from other regions of the country, mainly the Northeast and West (Table 6). However, this increment of in-migrants to the region was smaller than that of out-migrants. Overall, the Midwest had a negative net migration rate in 1985-90, thus reversing the positive rate of $1965-70$. 


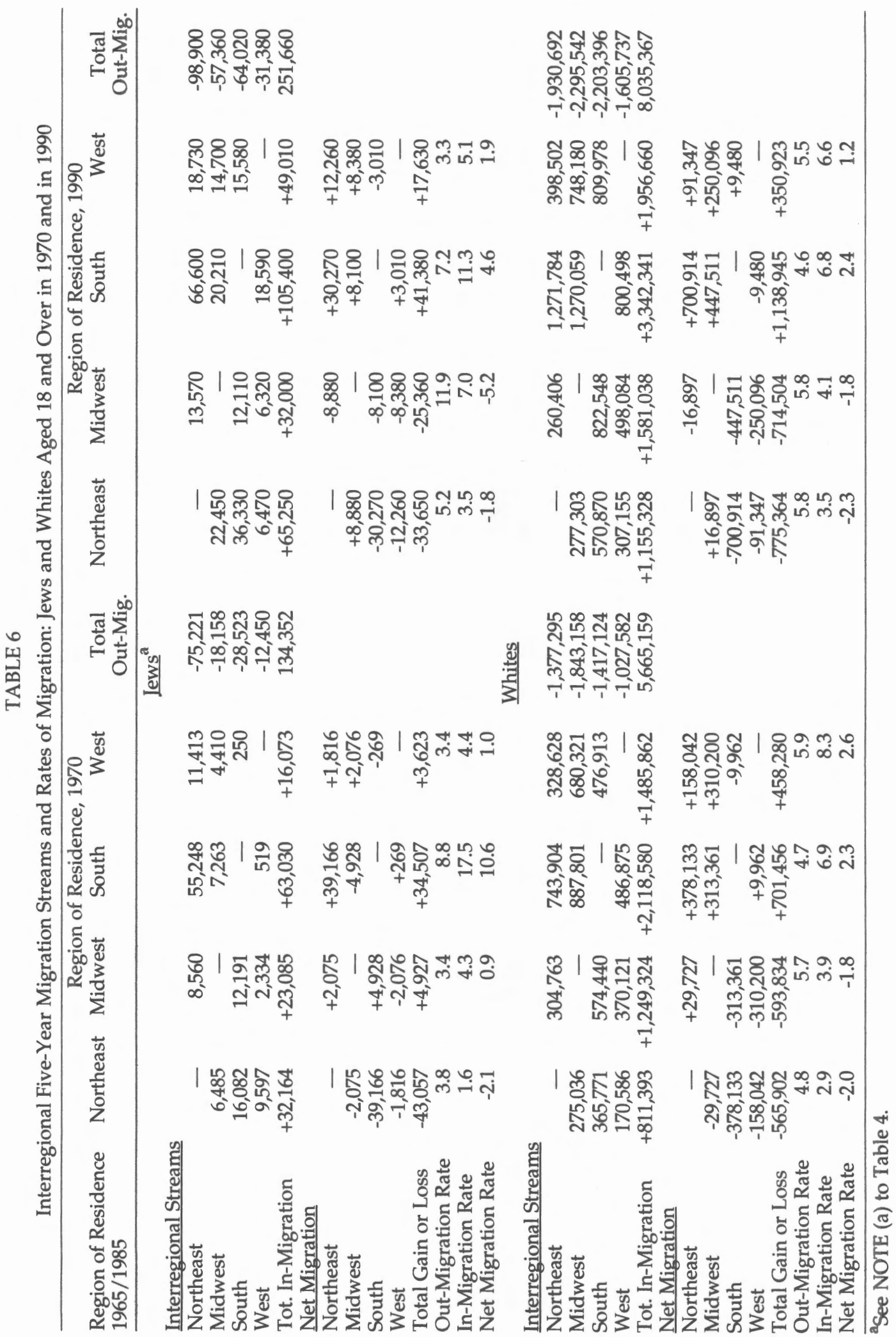


From 1965 to 1970, only a few hundred Jews moved between the two Sunbelt regions. However, by 1985-90, the South-to-West and West-to-South flows comprised slightly more than 15,000 persons each. This increase in both directions may be interpreted as "steady-region flows," which result from an established arrangement of social and economic functions between two regions, allowing for "normal levels of job turnover (and) job transfers" (Plane 1984, p. 297). Among the most significant changes in Sunbelt migration rates were the declines in the inmigration and net migration rates of the South.

FIGURE 2

Five-Year Migration Efficiency: Jews

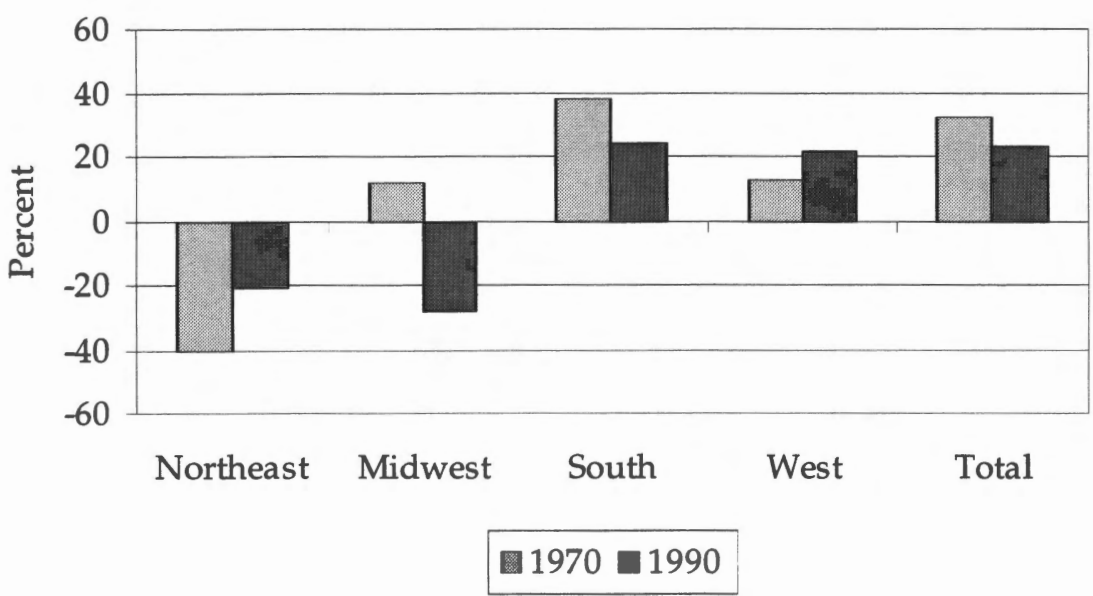

Five-Year Migration Efficiency: Total Whites

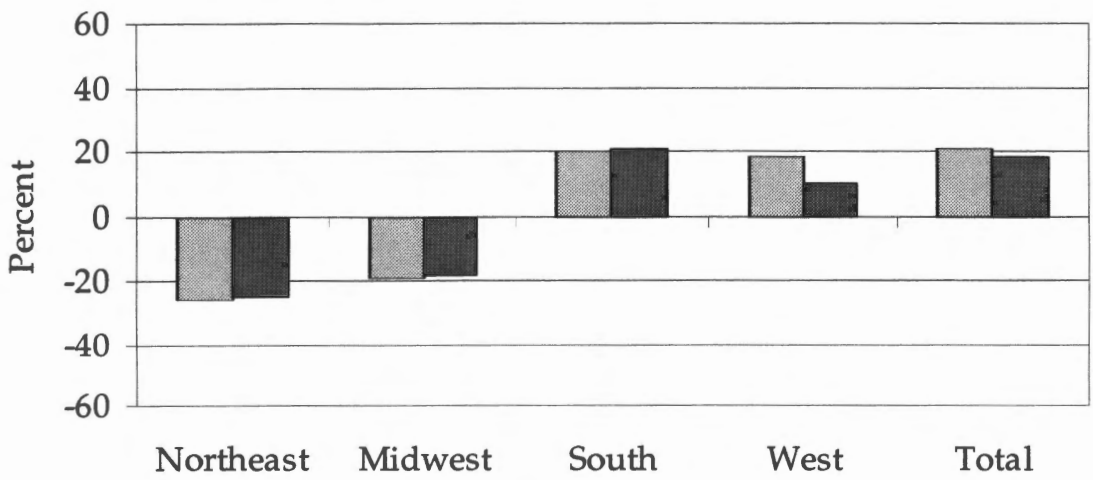

$1970 \square 1990$

Trends in the efficiency of migration point to the diminution in the amount of non-canceling migration out of the Northeast, while the Midwest experienced a marked reversal and by the late 1980s it had the most efficient net out-migration. Contradictory developments of reduction of the efficiency in the South and an 
increase in the West, resulted in the convergence of the migration efficiency of the two regions gaining Jewish population. Overall, five-year mobility in 1985-90 was less efficient in redistributing the Jewish population than in 1965-70 (Figure 2). This change implies increasing importance of countermovements, suggesting "growing heterogeneity of motivations for migration, so that more people have reasons to go to places where others are leaving" (Long 1988, p. 86). This finding stands in contradiction to the increase in the efficiency of lifetime migration that characterized the interval $1970-90$ as a whole; periodic socioeconomic developments seem to have interfered with this general trend.

\section{Total White Population}

With the exception of the Northeast, fewer Jews than whites who had changed their state of residence in the five years preceding the 1970 or 1990 Census had made an intraregional move (Table 5). The areas of origin of white interregional migration in 1965-70 show a larger proportion among migrants to the Northeast who originated in the Midwest as compared with the Jewish population. On the other hand, whites moving to the Midwest were less likely to come from the Northeast region. The state of origin for migrants from outside the South and the West varied and the proportion originating in the Northeast was significantly smaller than among Jews. Indeed, many whites moved between the two Sunbelt regions. By the late 1980s, the proportion of whites in the Midwest who have moved from the Northeast had declined, reflecting an inverse change to that which characterized the Jews. In contrast, the geographical behavior of Jews and whites had converged with respect to the proportion of migrants within the Sunbelt.

Five-year migration balances and trends between $1965-70$ and 1985-90 consistently point to losses for the Northeast and Midwest while the two Sunbelt regions were gaining white population (Table 6). Within this general process, some observations are particularly interesting: the shift of the Northeast to a positive net migration with the Midwest (similar to the trends among Jews); the diminution in the loss of the Northeast and Midwest to the West, although this remained substantial (while among Jews these net migrations increased); and the findings according to which the positive net migration to the South increased, whereas that to the West declined (among Jews, both Sunbelt regions experienced increases in net in-migration). Five-year movements between the two Sunbelt regions in 1965-70 were just as strong, amounting to about 480,000 whites in each direction. It is interesting that by 1985-90 the two migration streams had both increased to approximately 800,000 persons. This finding supports our previous conclusions concerning a "steady-region flow" between the South and the West that now seems to operate among groups of different socioeconomic compositions such as Jews and whites.

Over time, many of the migration rates of whites and Jews have converged. This can be seen in the migration rates for the Northeast, South, and West. 
However, in the West this is the result of different processes among the two subpopulations, with a slight decline in all measures of migration rates among whites as opposed to an increase among Jews. Only in the Midwest did the differentials between Jews and whites expand, with the former having higher rates in all three measures.

Among whites, migration efficiency to the West diminished by approximately one-half (Figure 2). In other regions, efficiency rates were found to be very similar in the two time intervals. The efficiency with which interregional migration brought about the redistribution of the white population remained fairly stable. In other words, countermovements among whites were as important in the late 1980 s as they had been two decades earlier. Finally, the data show the higher efficiency of Jews' interregional migration as compared to that of whites. However, over time these differentials diminished.

The above analysis suggests important trends in recent Jewish and total white migration, emphasizing the declining pull-power of the West and, to a lesser extent, of the South, while in-migration to the traditional core increased somewhat. Towards the late 1980s, the Midwest as a whole, and a few states in the eastern part of the region in particular (e.g., Indiana, Wisconsin), experienced a "manufacturing revival." Factories that had previously been closed were opened again, thereby providing new jobs. Between 1986 and 1990, capital expenditures per worker were 9 percent higher in the Midwest than in any other region (Florida 1996). Manufacturers prefer "external urbanized" areas with lower taxes, convenient access to transportation, and highly skilled workers (Rose 1994). The Midwest was fortunate in having more of the industries that were in the forefront of the United States economy during the late 1980s, which led to economic growth rates similar to the national average (Gober 1993).

In addition, the Midwest shifted into new and more advanced forms of production organization, and this was further enhanced by global integration of the local economy, "particularly by increased levels of foreign direct investment in manufacturing" (Florida 1996, p. 331). Such conditions turned the Midwest into a strong competitor vis-à-vis other regions, with the likelihood of attracting people in white-collar work as well as people engaged in manual labor, whose percentage among American Jews has recently increased (Goldstein 1992).

At the same time, globalization of manufacturing and services prefers coastal cities, such as New York, Los Angeles, and Miami. This enhanced their position as pillars of international business and centers of cultural and commercial creativity (McHugh and Gober 1992). Nevertheless, the economic crisis of the defense-related industries during the post-Cold War period might have significantly reduced the attractiveness of the West Coast, especially California. Moreover, large industries were "pulled" to other areas that offered strong economic incentives. Because a growing number of high-tech firms increased wages (Rogerson and Plane 1985), the advantage of this area over the industrial core was bound to decline. The difficult economic conditions were accompanied by high levels of 
crime (U.S. Bureau of the Census 1992) and relatively poor social services. A substantial proportion of those who left California came from the middle class, in which most of the Jews are concentrated.

\section{MULTIVARIATE ANALYSIS OF JEWISH INTERNAL MIGRATION: INDIVIDUAL CHARACTERISTICS, AREA CONTEXT OF RESIDENCE, AND GROUP IDENTITY ${ }^{6}$}

\section{The Contextual Framework}

This section examines the role of individual characteristics, socioeconomic and environmental conditions in area context of residence, and group identity as determinants of Jewish internal migration in the United States. The respective causal relationships of Jewish internal migration will be compared for 1965-70 and 1985-90. This approach of encompassing several levels of analysis simultaneously is in accordance with theoretical and research literature wherein different types of variables jointly create powerful mechanisms that lead to the cumulative causation of migration (Cadwallader 1992; Massey 1990).

Stages in the life cycle, including the acquiring of academic education, entering the job market, and changes in family status, often involve residential relocation (Bogue 1959; Goldscheider 1971; Greenwood 1985; Lee 1966; White and Mueser 1994). Since these events occur at a well-defined age interval, they shape the curve of migration selectivity by age with an overrepresentation of adolescents and young adults among migrants as compared to the total population (Long 1988; Ritchey 1976). Not only do these factors explain age selectivity, but they stand in their own right as determinants of migration behavior. For example, marital status involves different considerations and constraints on residential change; and socioeconomic stratification influences people's response to a set of push-and-pull forces in areas of origin and destination as well as their abilities to overcome obstacles that intervene on migration.

People with high educational attainment and occupational status have a better spatial awareness of social and economic opportunities in places other than those in which they live (Wolpert 1965). This "positive selection" may not hold for white-collar professionals who are locally licensed, or for people with locationspecific capital, such as a business (Bogue 1959; Long 1988). Although the association between migration and socioeconomic or marital status varies, depending on the specific variable (Ritchey 1976), the basic notion that individual characteristics determine migration behavior is supported by empirical works, including those focusing on internal and interregional migration (DaVanzo 1981; Kobrin and Speare 1983; Long 1988; Miller 1977).

Other studies emphasized that migration increases with industrialization and economic development, but at the same time becomes less selective (Browning 1971; Williamson 1965). The uncertainty as to opportunities and conditions in

${ }^{6}$ As indicated earlier, I used mainly published material of the 1970 and 1990 U.S. Censuses for describing the migration patterns of the total white population. I do not have the actual data files of these two Censuses to allow a parallel multivariate analysis for total whites. 
alternative areas is reduced, implying a larger and more heterogeneous migration stream. In this regard, migration is best understood in macro structural terms of the social and economic context of the area of residence and environmental concerns (Adamchak 1987; Greenwood 1969; Hunter 1998; Massey 1990). Spatial inequalities in employment opportunities and income, as well as other nonmonetary rewards, such as low crime rate and warmer climate, are cumulated to shape the individual's quality of life. As in other voluntary processes involving social and economic change, these structural forces encourage the attainment of the necessary threshold of desirability and feasibility of migration (Bass and Alexander 1972; Cebula and Vedder 1973; Clark and Hunter 1992; Michalos 1997).

A third attribute for variation in migration propensity is group identity (Gurak and Kritz 2000; Kobrin and Speare 1983; Tienda and Wilson 1992). A strong ethnoreligious commitment, involving high levels of communal participation as well as intensive interaction with kin and other compatriots, is likely to deter outmigration. Low migration would especially facilitate community bonds if the religious doctrine demands geographic proximity to house of worship and other parochial services (Cohen 1983).

\section{Measures}

The dependent variable tested here is five-year migration between the nine divisions of the United States. Nonmigrants (coded 0) are those who stayed in their beginning-of-period division of residence, and migrants (coded 1) are persons who departed to another division over the five-year interval examined. Such a geographic classification, as compared to the earlier focus on four major regions, increases the structural homogeneity of the geographic units examined. The nature of a binary dependent variable is appropriate for using logistic regression.

Explanatory individual characteristics include age, gender by marital status, education, and employment status. Age is treated as a continuous variable. Other covariates are measured as dummy variables.

I employed five measures to evaluate the effect of contextual conditions on interdivision migration: per capita income, unemployment rate, crime rate, funds for research and development in industry, and climate. These contextual measures are based on beginning-of-period data; exceptions are unemployment rate and climate. The former is the average of the mean total unemployment rate for each division for the five years of the respective interval; "the use of unemployment rates for several years should reduce problems of intertemporal fluctuations in relative rates of unemployment..." (Cebula and Vedder 1973, p. 207). I assume that most people prefer mild or warm climate to cold weather (Cebula 1975); thus, climate reflects the average percentage of possible days of sunshine for the largest cities for the period of record through 1969 (for the period 1965-70) and through 1990 (for the period 1985-90). The data were drawn from various official sources; they are introduced as continuous variables, and were attached to individual records. 
Group identity is expressed here by the denominational preferences of American Jews. Previous research indicated that ideological affiliation is an excellent explanatory variable of religious commitment and social integration (Lazerwitz et al. 1998; Rebhun 1993). Some of these studies demonstrated a linear model of identity, weakening from an identification with Orthodoxy to the Conservative and Reform denominations. According to the secularization-modernization thesis, nonaffiliation with one of these three major denominations is interpreted as the final stage preceding total assimilation (Goldscheider 1986). Denominational affiliation is likely to be differently associated with migration behavior. Observance of Jewish dietary laws, enrollment of children in Jewish day schools, and living a short distance from a synagogue and other ongoing religious services are among the major determinants of where to live and whether to migrate: "other things being equal, Orthodox families and individuals may be the most stable, since their choice of locations is most restricted; Conservative and Reform Jews as well as those who regard themselves as just Jewish may be more mobile because they have fewer observance-related constraints affecting their choice of residence" (Goldstein and Goldstein 1996, p. 176). Jewish denominational orientation was ranked according to persons' not defining themselves with any of the three major denominations of American Judaism (coded 0), defining themselves as Reform (coded 1), Conservative (coded 2) or Orthodox Jews (coded 3).

The means and standard deviations of all variables in the analysis are presented in Table 7. Among the Jewish population of 1970, 9 percent migrated between divisions in the preceding five years, versus 7 percent among the 1990 Jewish population. Both samples had similar mean ages, and were almost equally divided by gender. The proportion of currently married persons declined from 72 percent in 1970 to 63 percent in 1990, reflecting both later age at marriage and the increasing propensity for marriage dissolution. This change similarly characterized Jewish males and females. The educational profiles of the two populations depict significant variations; the percentage of those with college completion, and especially advanced academic degrees, was higher in 1990 with an addition of 13 percent for the two categories together. Over the period 1970-90, the proportion of self-employed increased from 14 to 21 percent.

Area characteristics reveal a salient increase in the average unemployment rate from the late 1960 s to the late 1980 s. At the same time, the crime rate per 100,000 population increased from 1,462 offenses in 1965 to 5,199 in 1985. Climatic conditions remained nearly unchanged. Data on per capita income and industrial research and development funds are given in current dollars, but inflation decreased the value of the dollar more than three times between 1970 and 1990 . Using Consumer Price Index (CPI-U), a mean per capita income of $\$ 2,987.53$ in 1970 equates to $\$ 10,067.98$ in 1990 dollars (an increase of $3.37 x$ ) yielding a 45.9 percent increase in real growth for a 1990 per capita income of $\$ 14,681.03$. Similarly, research and development funding experienced real growth of 55.7 percent between 1970 and $1990 .^{7}$

${ }^{7}$ I would like to thank one of the referees for providing the exact CPI-U and for making these calculations. 


\section{TABLE 7}

Definitions, Means and Standard Deviation of Variables Used in Logistic Regression

\begin{tabular}{|c|c|c|c|c|c|}
\hline \multirow[b]{2}{*}{ Variable } & \multirow[b]{2}{*}{ Definition } & \multicolumn{2}{|c|}{1970} & \multicolumn{2}{|c|}{1990} \\
\hline & & Mean & $\begin{array}{l}\text { Std. } \\
\text { Dev. }\end{array}$ & Mean & $\begin{array}{l}\text { Std. } \\
\text { Dev. }\end{array}$ \\
\hline$\frac{\text { Interdivisional Migration }}{\text { Migrant }}$ & $=1$ for Five-Year Interdivisional Migratio & .09 & 0.29 & .07 & 0.26 \\
\hline $\begin{array}{l}\text { Individual Characteristics } \\
\text { Age } \\
\text { Male Married } \\
\text { Male Not Married }^{\mathrm{a}} \\
\text { Female Not Married }^{\mathrm{a}} \\
\text { Some College }^{\mathrm{b}} \\
\text { Baccalaureate Degree }^{\mathrm{b}} \\
\text { M.A. Degree or Higher } \\
\text { Self-Employed }\end{array}$ & $\begin{array}{l}\text { In Years, } 18 \text { and Over } \\
=1 \text { for M Who is Currently Married } \\
=1 \text { for M Who is Currently Not Married } \\
=1 \text { for F Who is Currently Not Married } \\
=1 \text { for Some College } \\
=1 \text { for B.A.Diploma } \\
=1 \text { for M.A. or Higher, and Prof. Diplom } \\
=1 \text { for Self-Employed }\end{array}$ & 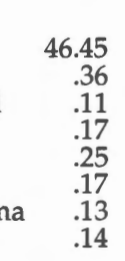 & $\begin{array}{r}17.63 \\
.48 \\
.31 \\
.38 \\
.43 \\
.38 \\
.33 \\
.35\end{array}$ & $\begin{array}{r}46.66 \\
.31 \\
.17 \\
.20 \\
.16 \\
.25 \\
.18 \\
.21\end{array}$ & $\begin{array}{r}18.38 \\
.46 \\
.38 \\
.40 \\
.37 \\
.43 \\
.39 \\
.41\end{array}$ \\
\hline $\begin{array}{l}\text { Area Context Variables } \\
\text { Per Capita Income } \\
\text { Unemployment Rate } \\
\text { Crime Rate } \\
\text { Industrial R\&D Funds } \\
\text { Climate }\end{array}$ & $\begin{array}{l}\text { In Dollars } \\
\text { In Percentage } \\
\text { Per } 100,000 \text { Population } \\
\text { In Millions of Dollars } \\
\text { Ave. Percentage of Possible Sunshine }\end{array}$ & $\begin{array}{r}2,987.53 \\
4.03 \\
1,462.31 \\
2,696.26 \\
59.75\end{array}$ & $\begin{array}{r}296.51 \\
.54 \\
340.57 \\
1,064.98 \\
6.32\end{array}$ & $\begin{array}{r}14,681.03 \\
5.84 \\
5,199.18 \\
14,141.53 \\
57.83\end{array}$ & $\begin{array}{r}1,290.54 \\
1.04 \\
786.27 \\
6,113.66 \\
4.05\end{array}$ \\
\hline$\frac{\text { Group Identity }}{\text { Jewish Denomination }}$ & $\begin{array}{l}0=\text { Other, } 1=\text { Reform, } 2=\text { Conservative, } \\
3=\text { Orthodox }\end{array}$ & 1.55 & .86 & 1.26 & .87 \\
\hline
\end{tabular}

a Reference category is female who is currently married.

bReference category is through high school graduation.

Over the period under discussion, the mean value of the denominational scale has declined from 1.55 to 1.26. This reflects significant shifts in the ideological preferences of American Jews from identification with Orthodoxy and the Conservative movements towards an increasing share of Reform Jews and those who do not identify with any of the major ideological denominations of American Judaism (Rebhun 1993).

\section{Results}

Logistic regression allows us to examine the effect of individual characteristics, area context variables, and group identity on interdivisional migration, relative to nonmigration, for the 1970 and 1990 Jewish populations. The first model in Table 8 evaluates the effects of individual characteristics (age, gender by marital status, education, and employment status) in determining migration. In Model 2, I added the area socioeconomic and environmental context (income, unemployment, crime, industrial research and development funds, and climate). Model 3 incorporates all these independent variables, including denominational identification. The relationships between the independent variable and migration are presented as odds ratios (exp[b]), which express the relative odds of the event (migra-

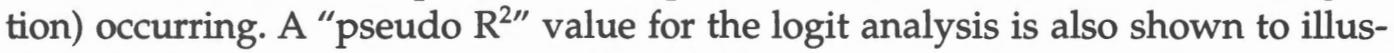
trate the explanatory power of each model.

With only two exceptions, the covariates in Model 1 of the 1970 Jewish population were significant. They show that migration decreased with age. All other things being equal, not being married implied a lower probability of moving from one division to another. This weaker propensity of the nonmarried to move is somewhat more pronounced among males than among females. Education, 
particularly advanced academic degrees and professional diplomas, greatly increased the odds of migration: the group with the highest academic attainment was more than three times as likely to move to another division than that with education only through high school. Self-employment reduced the probability of migration.

\section{TABLE 8}

Logistic Regressions (Odds Ratios) of Jewish Interdivisional Migration on Individual Characteristics, Socioeconomic Context of Residence, and Jewish Identity, 1965-70 and 1985-90

\begin{tabular}{|c|c|c|c|c|c|c|}
\hline Variable & Model 1 & $\frac{1965-70}{\text { Model } 2}$ & Model 3 & Model 1 & $\frac{1985-90}{\text { Model } 2}$ & Model 3 \\
\hline \multicolumn{7}{|l|}{ Individual Characteristics } \\
\hline Age & $.961^{* * *}$ & $.955^{* * *}$ & $.967^{* * *}$ & $.968^{* * *}$ & $.967^{* * *}$ & $.964^{* * *}$ \\
\hline Male Married & .891 & .970 & 1.199 & 1.092 & 1.055 & 1.054 \\
\hline Male not Married & $.302^{* * *}$ & $.268^{* * *}$ & $.394^{* * *}$ & $1.563^{*}$ & $1.505^{*}$ & 1.414 \\
\hline Female not Married & $.511^{* * *}$ & $.463^{* * *}$ & $.681^{* *}$ & 1.211 & 1.208 & 1.180 \\
\hline Some College & .822 & .862 & 1.006 & .956 & .987 & .957 \\
\hline Baccalaureate Degree & $1.922^{* * *}$ & $2.006^{* * *}$ & $1.761^{* * *}$ & $1.858^{* * *}$ & $1.853^{* * *}$ & $1.921^{* * *}$ \\
\hline M.A. Degree or Higher & $3.813^{* * *}$ & $3.796^{* * *}$ & $4.118^{* * *}$ & $1.798^{* *}$ & $1.811^{* *}$ & $1.910^{* *}$ \\
\hline Self-Employed & $.599 * * *$ & $.511^{* * *}$ & $.520^{* * *}$ & .745 & .756 & .752 \\
\hline \multicolumn{7}{|l|}{ Area Context Variables } \\
\hline Per Capita Income & & $1.000^{* * *}$ & $1.001^{* * *}$ & & $1.000^{*}$ & $1.000^{*}$ \\
\hline Unemployment Rate & & $1.968^{* * *}$ & $1.417^{*}$ & & $1.586^{* * *}$ & $1.584^{* * *}$ \\
\hline Crime Rate & & $.998^{* * *}$ & $.998^{* * *}$ & & .999 & .999 \\
\hline Industrial R\&D Funds & & $.999 * * *$ & $.999 * * *$ & & $.999^{* * *}$ & $.999^{* * *}$ \\
\hline Climate & & $1.064^{* * *}$ & $1.101^{* * *}$ & & .960 & .975 \\
\hline \multicolumn{7}{|l|}{ Jewish Identity } \\
\hline Jewish Denomination & & & $.700^{* * *}$ & & & .952 \\
\hline-2 Log Likelihood & 5474.860 & 5105.289 & 4534.552 & 1639.479 & 1595.109 & 1524.083 \\
\hline Chi-Square & 610.230 & 816.871 & 742.282 & 98.284 & 142.654 & 150.045 \\
\hline Pseudo $\mathrm{R}^{2}$ & $10.0 \%$ & $13.8 \%$ & $14.1 \%$ & $5.7 \%$ & $8.2 \%$ & $9.0 \%$ \\
\hline
\end{tabular}

${ }^{*} \mathrm{P}<.05 ;{ }^{* *} \mathrm{p}<.01$; ${ }^{* * *} \mathrm{p}<.001$

a Based on data from NJPS.

No meaningful changes appeared in the relationships between individual characteristics and migration after controlling for socioeconomic context of residence (Model 2). This model for 1970 shows that the unemployment rate in the late 1960s had a significant and positive effect on interdivisional migration. The odds of migrating climbed to the level of 1.968 , thus confirming the theoretical notion as well as many empirical findings that people move away from places with structural disadvantages, among which job opportunities are paramount (Bass and Alexander 1972; Clark and Hunter 1992; Greenwood 1985). The climate measure shows, somewhat unexpectedly, a positive and significant relation to migration. The odds ratio of 1.064 indicates that persons living in 1965 in areas with higher percentages of sunny days were somewhat more likely to have moved to another area by 1970 than were people living in areas with lower percentages of sunny days. Warm climate is an important determinant of migration for the elderly; however, the majority of the adult population is more likely to be concerned with economic conditions and lifestyles as applicable to young and 
middle-aged couples and their children. The other three measures of contextual conditions also had statistically significant relations with the dependent variable (at $\mathrm{p}<.001$ ). Nevertheless, a large change in these independent variables led to only a small change in the probability of moving interdivisionally.

After controlling for individual characteristics and area context of residence, it may be asserted that denominational identification has a negative and statistically significant relation to migration (Model 3). The odds ratio of .700 indicates that Jews who were affiliated with the more rigorous denominations were less likely to move to another division than were those who identified themselves with Reform Judaism or lacked any ideological preference. Note that the Variance Inflation Factors (VIF) show no problem of multicollinearity, with all VIFs in the full model being smaller than 8 (most are smaller than 3 ).

For the period 1985-90, only four of the individual characteristics had a significant effect on interdivisional migration: age, gender and marital status of nonmarried male, baccalaureate degree, and M.A. or higher degree or professional diploma (Model 1). Interestingly, the relationship between gender by marital status and migration reversed itself from negative to positive over time. A two-sample ttest shows that the coefficients of the variables male and female not married from the 1990 equation are significantly different from their corresponding coefficients of the 1970 equation (Appendix A1). These results point to an important social and cultural transition among Jews, and presumably within American society in general, according to which not being married does not deter out-migration. If this status today has any effect at all, it increases the likelihood of males to move (although this relation was found to be statistically insignificant after controlling for area variables and Jewish denomination). Our findings largely coincide with previous observations that show that, despite some delay among young adults in the 1980s to leave home, "they lived away from parents longer than unmarried young people had done in the past" (Goldscheider and Goldscheider 1994, p. 4). Moreover, in comparison to other religious groups, Jews underwent the greatest increase in nest-leaving. While this is associated with the importance that Jews place on education, along with a strong aspiration for developing a career, it also attests to changing values (among young adults and their parents) in regard to new living arrangements, gender roles, the need for independence and, more generally, to processes of secularization.

The positive odds ratio for education, especially for advanced degrees, was lower than that found twenty years earlier. Much of this decline can be attributed to recurrent recessions, decline in job opportunities, and slow wage growth in the 1980s and early 1990s (i.e., decline in labor market returns for educational skills), which especially affected advanced hi-tech industries. Model 2 reveals similar trends for the contextual measures. Crime rate and climate were no longer significant predictors of interdivisional migration, and the probability to migrate with the increase in unemployment rate was moderated.

By 1990, the effect of Jewish denomination on interdivisional migration had become statistically insignificant. This change is meaningful, as revealed by 
the two-sample t-test (Appendix A1). However, it does not indicate any decline in the importance of religious participation and communal life according to ideological preferences. The correlation between denominational identification and such behaviors as synagogue membership, Jewish organizational membership, or involvement in informal networks composed mainly of other Jews remained strong and statistically significant (Rebhun 1997b). Rather, this suggests that, unlike the past when Jews were highly concentrated in a limited number of states, mainly ports of entry in the Northeast, the more recent internal migrations resulted in wider and more even dispersion throughout the United States. Jewish religious and parochial services of the different denominations had already developed in different places thus allowing adherence to the preferred ideological orientation with its accompanying religious practices. The VIF test shows no multicollinearity for the 1990 data.

The last row of Table 8 shows, for each model, the explanatory power of the differences in interdivisional migration. Individual characteristics accounted for 10 percent of the variation in Jewish migration between 1965 and 1970. After adding the contextual variables, 13.8 percent of the variation in interdivisional migration was statistically explained by the independent variables. This was further increased to 14.1 percent in the full model. The explanatory power for the parallel models in 1985-90 declined to $5.7,8.2$, and 9 percent, respectively.

Largely in accordance with the general white population (Greenwood 1969; Kobrin and Speare 1983; Long 1988; Ritchey 1976), Jewish migration is affected by educational attainment, and is also sensitive to macro conditions of employment opportunities and industrial development. Over time, however, Jewish migrants became less selective; they were more evenly spread along different socioeconomic strata and denominational categories. We might infer that, due to the successful integration into, and acceptance by, the general social mainstream, migration has become a widespread phenomenon among American Jews. Apart from considering economic benefits and material well-being, the residential preferences of the Jews take into account social, cultural, and political stimuli. As a religious minority that has become comfortable and deeply rooted in the local scene of America, it is likely that their areas of settlement will develop in directions similar to those of their non-Jewish counterparts.

\section{SUMMARY AND DISCUSSION}

Over the period 1970-90, the directions of interregional lifetime and fiveyear migration among Jews and total whites were similar. They can be summarized as a tendency to leave the Northeast and the Midwest in favor of the Sunbelt regions. By 1990, however, net migration for each region-both the gaining region and the losing region-had a more significant effect on Jewish than on white population redistribution. Jewish migration was mainly motivated by educational attainment, but socioeconomic conditions in the area of residence, especially employment opportunities, were also important explanatory determinants 
of geographic preferences. Denominational affiliation, which in the late 1960s acted to deter out-migration, is no longer a significant predictor of migration behavior.

Interregional movement had only a moderate impact on the regional distribution of total whites, while migration of the Jews led to substantially decreased concentrations in their traditional areas of settlement in the Northeast and Midwest, and to increased concentrations in the South and the West. These migration patterns resulted in greater residential similarity with other white groups in terms of basic regional distribution: the index of dissimilarity (based on four regions) declined from .36 in 1970 to .25 in 1990.

The blurring geographical distinctiveness of American Jews was likewise evident at the level of states and residential neighborhoods. I calculated the divergence of the geographic distribution of Jews from that of total whites in the 50 states (including the District of Columbia). The index of dissimilarity declined from .44 in 1970 to .42 in 1990. The small magnitude of change suggests that the unique social status of American Jews directs them to a limited number of major states and metropolises within a given region, where economic activities correspond to their professional qualifications. The national Jewish population surveys asked respondents to describe the Jewish character of their neighborhood as either not at all, a little, somewhat, or very Jewish. This subjective judgment shows that, while in 1970 as many as two-thirds said that they lived in a somewhat or very Jewish neighborhood, in 1990 this was true for only 39 percent. This tendency away from Jewish residential clustering consistently appears from the complementary perspectives of intergenerational change, as seen in the variation between different age groups at a given time; period change, as seen in the differences between similar age groups at different points of time; and life-cycle change, as the same cohort passes from one to the next stage of life. ${ }^{8}$

The redistribution patterns of American Jews point to their successful integration into, and acceptance by, the majority society, while the response of Jews to regional opportunity has come to resemble that of other white Americans. The residential preferences of the Jews are more likely to be motivated by economic opportunities and a search for amenities than by the salience of kinship ties and ethnic networks. This indicates the declining role of group particularism in determining migration behavior among American Jews and, more generally, supports the view of the weakening importance of ethnicity in contemporary America.

${ }^{8}$ The Jewish Character of Residential Neighborhood:

American Jews aged 18 and over in 1970 and in 1990 (Percent)

\begin{tabular}{lrrrrr}
\hline & Total & $18-37$ & $38-57$ & $58-77$ & 78 and Over \\
\hline 1970 - Total & 100.0 & 100.0 & 100.0 & 100.0 & 100.0 \\
Not at all or a little Jewish & 31.6 & 32.4 & 33.0 & 29.4 & 18.5 \\
Somewhat Jewish & 38.6 & 39.3 & 37.1 & 38.4 & 50.5 \\
Very Jewish & 29.8 & 28.2 & 29.9 & 32.1 & 31.0 \\
& & & & & 100.0 \\
1990 - Total & 100.0 & 100.0 & 100.0 & 100.0 & 43.6 \\
Not at all or a little Jewish & 61.4 & 68.0 & 65.1 & 50.2 & 40.7 \\
Somewhat Jewish & 28.9 & 23.9 & 27.8 & 35.2 & 15.7 \\
Very Jewish & 9.8 & 8.1 & 7.2 & 14.6 & \\
\hline
\end{tabular}


From the standpoint of the Jewish group, its physical density is waning. The proximity to family and peers is becoming less important, and the choice of destination by Jewish migrants is facilitating their interaction with people of other faiths and ethnic background. Among other things, this is evidenced by regional variation of intermarriage. In 1990, the proportion of married Jews with a non-Jewish spouse who had not undergone any form of conversion was 6 percent higher in the West than in the Northeast. Since opportunities for mate selection are affected by community size, with the likelihood of marrying a coreligionist being higher in areas of large Jewish population (Rabinowitz 1989), I also looked at specific communities of relatively similar size. These comparisons, for the late 1980s, are consistent with the above differences. While the intermarriage rate in Dallas, Texas, with a Jewish population of 33,000, was 13 percent of all married Jews, this rate was only 4 percent in Rhode Island, which is a much smaller community of 16,000 Jews. The rates for Denver, Colorado, and Monmouth, New Jersey-each with a Jewish population of approximately 65,000-were 26 percent and 9 percent, respectively (Sheskin 2001).

Moreover, the direction of Jewish spatial movements is from the older Jewish centers in the Northeast, which possess strong organizational infrastructures, to Sunbelt cities, many of which are characterized by greater religious and cultural pluralism-a "majestic openness" (Graham 1983, p. 8). In these areas, new forms of humanism and creative needs outweigh old styles of religion and ethnicity. This new social and cultural environment may reinforce self-selected identity and weaken religioethnic identity (Graham 1983; Moore 1992). I found that, all other things being equal, living in the Los Angeles area had a statistically significant and negative effect on the level of Jewish identification as compared to living in Philadelphia or Greater Boston (Rebhun 1995). Community of residence accounted for a large proportion of the total variation explained by the independent variables. Likewise, residence in Los Angeles persisted as a factor correlated with a lower level of Jewishness for two- to five-way interaction effects, whereas residence in Greater Boston was correlated with a higher level of Jewishness. Taken together, these trends may have implications also on the public cohesiveness and distinctiveness of the Jewish communities in these areas of accelerated settlement.

Finally, a 2000/2001-NJPS is being conducted. The results, together with data from the new decennial Census, will allow us to extend the analysis of the processes of Jewish spatial assimilation and, more generally, of the changing residential patterns in the multiethnic context of American society. 


\section{APPENDIX A1}

Two-Sample T-Test for Assessing the Significance of the Differences Between Coefficients: Interdivisional Migration, $1965-70$ and $1985-90^{\text {a }}$

\begin{tabular}{lccc}
\hline & Model 1 & Model 2 & Model 3 \\
\hline Age & 1.134 & 2.280 & 0.472 \\
Male Married & 0.967 & 0.397 & 0.591 \\
Male Not Married & 6.748 & 6.899 & 4.931 \\
Female Not Married & 3.661 & 3.979 & 2.216 \\
Some College & 0.562 & 0.499 & 0.176 \\
Baccalaureate Degree & 0.173 & 0.394 & 0.409 \\
M.A. Degree or Higher & 3.413 & 3.299 & 3.323 \\
Self-Employed & 0.980 & 1.714 & 1.582 \\
Per Capita Income & & $\mathbf{2 . 6 8 3}$ & $\mathbf{3 . 4 7 8}$ \\
Unemployment Rate & & $\mathbf{4 . 9 1 9}$ & $\mathbf{4 . 4 3 7}$ \\
Crime Rate & & 1.155 & 0.558 \\
Industrial R \& D Funds & & 3.343 & $\mathbf{3 . 7 8 4}$ \\
Climate & & 0 & 0 \\
Jewish Denomination & & & $\mathbf{3 . 1 8 4}$ \\
\hline
\end{tabular}

a)

$$
\frac{\left|\mathrm{B}_{1970}-\mathrm{B}_{1990}\right|}{\sqrt{\mathrm{SE}_{1970}^{2}+\mathrm{SE}_{1990}^{2}}}
$$

\section{REFERENCES}

Adamchak, D.J. "Further Evidence on Economic and Noneconomic Reasons for Turnaround Migration." Rural Sociology 52 (1987), 108-118.

Alba, R.D. Ethnic Identity: The Transformation of White America. New Haven and London: Yale University Press, 1990.

Assadian, A. "Fiscal Determinants of Migration to a Fast-Growing State: How the Aged Differ from the General Population." The Review of Regional Studies 25 (1995), 301-315.

Barff, R.A., and P.L. Knight. "The Role of Federal Military Spending in the Timing of the New England Employment Turnaround." Papers of the Regional Science Association 65 (1988), 151-166.

Bass, B.M., and R.A. Alexander. "Climate, Economy, and the Differential Migration of White and Nonwhite Workers." Journal of Applied Psychology 56 (1972), 518-521.

Bean, F.D., M. Tienda, and D.S. Massey. "Geographical Distribution, Internal Migration, and Residential Segregation." In F.D. Bean and M. Tienda (eds.) The Hispanic Population of the United States, 137-177. New York: Russell Sage Foundation, 1987.

Belanger, A., and A. Rogers. "The Internal Migration and Spatial Redistribution of the Foreign-Born Population in the United States: 1965-70 and 1975-80." International Migration Review 26 (1994), 1342-1369.

Bogue, D.J. The Population of the United States. New York: The Free Press, 1959. 
Browning, H.L. "Migration Selectivity and the Growth of Large Cities in Developing Societies." In National Academy of Sciences, Rapid Population Growth: Consequences and Policy Implications, 273-314. Baltimore: Johns Hopkins University Press, 1971.

Cadwallader, M. Migration and Residential Mobility: Macro and Micro Approaches. Madison: The University of Wisconsin Press, 1992.

Cebula, R.J. "Migration, Economic Opportunity, and the Quality of Life: An Analysis for the United States According to Race, Sex, and Age." Annals of Regional Science 9 (1975), 127-133.

Cebula, R.J., and R.K. Vedder. "A Note on Migration, Economic Opportunity and the Quality of Life." Journal of Regional Science 13 (1973), 205-211.

Clark, D.E., and W.J. Hunter. "The Impact of Economic Opportunity, Amenities and Fiscal Factors on Age-Specific Migration Rate." Journal of Regional Science 32 (1992), 349-365.

Cohen, S.M. American Modernity and Jewish Identity. New York and London: Tavistock Publication, 1983.

DaVanzo, J. "Microeconomic Approaches to Studying Migration Decisions." In G.F. DeJong and R.W. Gardner (eds.) Migration Decision Making, 91-127. New York: Pergamon, 1981.

DellaPergola, S. "Jewish Women in Transition: A Comparative Sociodemographic Perspective." Studies in Contemporary Jewry 16 (2000), 209-242.

Fishman, S.B. "The Changing American Jewish Family Faces the 1990s." In R.R. Farber and C.I. Waxman (eds.) Jews in America: A Contemporary Reader, 51-88. Hanover and London: University Press of New England, Brandeis University Press, 1999.

Florida, R. "Regional Creative Destruction: Production Organization, Globalization, and the Economic Transformation of the Midwest." Economic Geography 72 (1996), 314-334.

Frey, W.H. "The New Geography of Population Shifts." In Reynolds Farley (ed.) The State of the Union in the 1990s, Social Trends, 271-355. New York: Russell Sage Foundation, 1995a.

. "Immigration and Internal Migration 'Flight': A California Case Study." Population and Environment: A Journal of Interdisciplinary Studies 16 (1995b), 353-375.

Gans, H.J. "Symbolic Ethnicity and Symbolic Religiosity: Towards a Comparison of Ethnic and Religious Acculturation." Ethnic and Racial Studies 17 (1994), 577-592.

Gober, P. "Americans on the Move." Population Bulletin 48 (1993).

Goldscheider, C. Population, Modernization and Social Structure. Boston: Little, Brown and Company, 1971.

. Jewish Continuity and Change: Emerging Patterns in America. Bloomington: Indiana University Press, 1986.

Goldscheider, F., and C. Goldscheider. "Leaving and Returning Home in 20th Century America." Population Bulletin 48 (1994). 
Goldstein, S. "Facets of Redistribution: Research Challenges and Opportunities." Demography 13 (1976), 423-434.

. "Population Movement and Redistribution among American Jews." In U.O. Schmelz, P. Glikson, and S. DellaPergola (eds.) Papers in Jewish Demography 1981, 315-341. Jerusalem: The Institute of Contemporary Jewry, The Hebrew University of Jerusalem, 1983.

. "Profile of American Jewry: Insights from the 1990 National Jewish Population Survey." American Jewish Year Book 92 (1992), 77-173.

Goldstein, S., and A. Goldstein. Jews on the Move: Implications for Jewish Identity. Albany: State University of New York Press, 1996.

Graham, O.L. "From Snowbelt to Sunbelt: The Impact of Migration." Dialogue 59 (1983), 8-15.

Greenwood, M.J. "An Analysis of the Determinants of Geographic Labor Mobility in the United States." The Review of Economics and Statistics 51 (1969), 189-194. . "Human Migration: Theory, Models, and Empirical Studies." Journal of Regional Science 25 (1985), 521-544.

. "Changing Patterns of Migration and Regional Economic Growth in the U.S.: A Demographic Perspective." Growth and Change: A Journal of Urban and Regional Policy 19 (1988), 68-87.

Gurak, D.T., and M.M. Kritz. "Context Determinants of Interstate Migration of U.S. Immigrants." Social Forces 78 (2000), 1017-1039.

Hunter, L.M. "The Association Between Environmental Risk and Internal Migration Flows." Population and Environment: A Journal of Interdisciplinary Studies 19 (1998), 247-277.

Kobrin, F.E., and A. Speare, Jr. "Out-migration and Ethnic Communities." International Migration Review 17 (1983), 425-444.

Kritz, M.M., and D.T. Gurak. "The Impact of Immigration on the Internal Migration of Natives and Immigrants." Demography 38 (2001), 133-145.

Lazerwitz, B., J.A. Winter, A. Dashefsky, and E. Tabory. Jewish Choices: American Jewish Denominationalism. Albany: State University of New York, 1998.

Lee, A.S. "Return Migration in the United States." International Migration Review 8 (1974), 283-300.

Lee, E.S. "A Theory of Migration." Demography 3 (1966), 47-57.

Lee, S., and C.C. Roseman. "Migration Determinants and Employment Consequences of White and Black Families, 1985-1990." Economic Geography 75 (1999), 109-133.

Lipset, S.M., and E. Raab. Jews and the New American Scene. Cambridge and London: Harvard University Press, 1995.

Long, L. Migration and Redistribution Mobility in the United States. New York: Russell Sage Foundation, 1988.

Long, L.H., and K.A. Hansen. "Trends in Return Migration to the South." Demography 12 (1975), 601-614.

Massey, D.S. "Social Structure, Household Strategies, and the Cumulative Causation of Migration." Population Index 56 (1990), 3-26. 
Massey, D.S., and B.P. Mullan. "Processes of Hispanic and Black Spatial Assimilation." American Journal of Sociology 89 (1984), 836-873.

McHugh, K.E., and P. Gober. "Short-Term Dynamics of the U.S. Interstate Migration System, 1980-1988." Growth and Change: A Journal of Urban and Regional Policy 23 (1992), 428-444.

Michalos, A.C. "Migration and the Quality of Life: A Review Essay." Social Indicators Research 39 (1997), 121-166.

Miller, A.R. "Interstate Migrants in the United States: Some Social-Economic Differences by Type of Move." Demography 14 (1977), 1-17.

Moore, D.D. "Jewish Migration in Postwar America: The Case of Miami and Los Angeles." Studies in Contemporary Jewry 8 (1992), 102-117.

Novak, M. The Rise of Unmeltable Ethnics. New York: Macmillan, 1972.

Plane, D.A. "A Systematic Demographic Efficiency Analysis of U.S. Interstate Population Exchange, 1935-1980." Economic Geography 60 (1984), 294-312.

. "Population Migration and Economic Restructuring in the United States." International Regional Science Review 12 (1989), 263-280.

Rabinowitz, J. "The Paradoxical Effects of Jewish Community Size on Jewish Communal Behavior: Intermarriage, Synagogue Membership and Giving to Local Jewish Federations." Contemporary Jewry 10 (1989), 9-15.

Rebhun, U. "Trends in the Size of American Jewish Denominations: A Renewed Evaluation." CCAR Journal: A Reform Jewish Quarterly Winter Issue (1993), 1-11.

. "Geographic Mobility and Religioethnic Identification: Three Jewish Communities in the United States." Journal for the Scientific Study of Religion 34 (1995), 485-498.

. "Changing Patterns of Internal Migration 1970-1990: A Comparative Analysis of Jews and Whites in the Unites States." Demography 34 (1997a), 213-223.

. "Geographic Mobility and Religioethnic Identification among American Jews 1970-1990." Ph.D. diss., The Hebrew University of Jerusalem, $1997 b$.

Ritchey, N.P. "Explanations of Migration." Annual Review of Sociology 2 (1976), 363-404.

Rogerson, P., and D.A. Plane. "Monitoring Migration Trends." American Demographics 7 (1985), 27-29, 47.

Rose, R. "New Life to the Rusty Belt." Wall Street Journal, 4 January 1994.

Sandefur, G.D. "American Indian Migration and Economic Opportunities." International Migration Review 20 (1986), 55-68.

Sandefur, G.D., and J. Jeon. "Migration, Race and Ethnicity, 1960-1980." International Migration Review 25 (1991), 392-407.

Serow, W.J. "Changes in the Composition of Migration for States: 1955-60 to 1965-70." The Review of Regional Studies 5 (1975), 12-28.

Sheskin, I.M. How Jewish Communities Differ: Variations in the Findings of Local Jewish Population Studies. New York: North American Jewish Data Bank, 2001. 
Tienda, M., and F.D. Wilson. "Migration and the Earnings of Hispanic Men." American Sociological Review 57 (1992), 661-678.

U.S. Bureau of the Census. Statistical Abstract of the United States, 1992. Washington, D.C.: U.S. Government Printing Office, 1992.

White, M.J., and P.R. Mueser. "Changes in the Demographic Determinants of U.S. Population Mobility: 1940-1980." The Review of Regional Studies 24 (1994), 245-264.

Williamson, J.F. "Regional Inequality and the Process of National Development: A Description of the Patterns." Economic Development and Cultural Change 13 (1965), 3-84.

Wolpert, J. "Behavioral Aspects of the Decision to Migrate." The Regional Science Association Papers 15 (1965), 159-169.

Wright, R.A., M. Ellis, and M. Reibel. "The Linkage Between Immigration and Internal Migration in Large Metropolitan Areas in the United States." Economic Geography 73 (1997), 234-254. 